\title{
Normative and systems integration in human resource management in Japanese multinational companies
}

Article

Accepted Version

Furusawa, M., Brewster, C. and Takashina, T. (2016) Normative and systems integration in human resource management in Japanese multinational companies. Multinational Business Review, 24 (2). pp. 82-105. ISSN 1525383X doi: https://doi.org/10.1108/MBR-03-2015-0011 Available at https://centaur.reading.ac.uk/65590/

It is advisable to refer to the publisher's version if you intend to cite from the work. See Guidance on citing.

To link to this article DOI: http://dx.doi.org/10.1108/MBR-03-2015-0011

Publisher: Emerald

All outputs in CentAUR are protected by Intellectual Property Rights law, including copyright law. Copyright and IPR is retained by the creators or other copyright holders. Terms and conditions for use of this material are defined in the End User Agreement.

www.reading.ac.uk/centaur 
Central Archive at the University of Reading

Reading's research outputs online 


\section{Normative and systems integration in Human Resource Management in Japanese multinational companies}

\section{Introduction}

International Human Resource Management (IHRM) explores the way that people are managed in organisations operating across national boundaries. "As commonly defined, international HRM ... deals with the human resource management practices and outcomes in ... MNCs (multinational companies)" (Kaufman, 2014, p. 4). This article draws on evidence of IHRM in 93 large Japanese MNCs, and noting the issues of location in the eclectic paradigm of international business (Dunning and Lundan, 2008; Eden, 2003; Narula, 2010; Pangarkar and Yuan, 2009) addresses the 'other side of the coin' - the need for integration. We develop a model of 'transnational human resource management' and demonstrate its validity.

The 'transnational company' concept (Bartlett and Ghoshal, 1989, 1995 and 1998) suggests that the source of competitive advantage of MNCs today lies in worldwide learning capabilities that create, transfer, and utilise innovation globally by leveraging locally-embedded knowledge. 'Transnational innovation processes' include both locally leveraged innovation and globally linked innovation. We take our definition of innovation from Janssen (2000), who defined it as: "the intentional creation, introduction and application of new ideas within a work role, group or organization, in order to benefit role performance, the group, or the organization" (Janssen, 2000, p. 288). Locally leveraged innovation involves capitalizing on the resources and entrepreneurship of individual subsidiaries to create innovations that can be exploited on a worldwide basis, whilst globally linked innovation connects the resources and 
capabilities of diverse worldwide units in the company to create and implement innovations on a joint basis (Bartlett and Ghoshal, 1989, p.116).

In a similar vein, Doz, Santos, and Williamson (2001, p.1) advocate the 'metanational company model', also insisting that the challenge of MNCs is to innovate by learning from across the world with each overseas subsidiary contributing to the global operations network by developing unique, site-specific capabilities. They argue that an ideal metanational company is finely tuned to sense, mobilize and leverage pockets of specialist knowledge dispersed around the globe in a highly interdependent organisation. Localisation strategies without global integration might make the overseas subsidiaries 'uncontrollable kites' that end up as a medley of stand-alone companies (Furusawa, 2014, p. 160) so, from the perspective of IHRM, executives of overseas subsidiaries in the transnational or metanational company are required to contribute to the whole global organisation, in addition to being experts at squeezing the greatest distinctiveness out of their local environment (Evans, Pucik, and Barsoux, 2002, p. 203). Accordingly, MNCs today have to establish IHRM policies and practices that will promote global collaboration amongst managers who are culturally diverse and geographically dispersed at the same time as they localise the top management positions of their overseas subsidiaries for local responsiveness.

Studies of 'transnationality', or organisational capabilities required of transnational company have generally been conducted from the perspective of international business strategy and this has not been followed through enough in terms of international human resource management. Moreover, so far only limited research has been carried out on the global integration aspect of international human resource management in Japanese multinationals (Furusawa, 2014). With these points in mind, 
we attempt to address the research gap by bridging the discussion between international business and international HRM. In this paper we specify and explore the dimensions of global HRM integration that might contribute to the enhancement of the transnationality of MNC and develop a theoretical model of the mechanisms for such global HRM integration. We use a sample of major Japanese MNCs to explore the model empirically and examine the degree of transnationality of those MNCs. We explain the relationship between global HRM integration and transnationality by examining two underlying mechanisms (mediating variables): enhancing social capital and global mobility of workforces.

The article takes the following form. We discuss relevant aspects of the IHRM literature as related to the issues of globalisation and localisation and develop a model of different forms of integration, from which we create hypotheses. Next we explain our methodology to test the hypotheses and present our findings. Finally, we draw implications for the IHRM policies and practices of Japanese MNCs from both the theoretical and practical points of view.

\section{Literature review and hypotheses development}

In line with the discussion on the dualistic pressures of local responsiveness and global integration in international business, the management of duality has become a key concern in the field of IHRM (Chung, Bozkurt, and Sparrow, 2012). To date, two aspects have been highlighted in the IHRM literature. One is the degree of global standardisation versus localisation of subsidiary HRM practices within the MNC; and the other is the utilisation of parent country nationals (PCNs) versus host country nationals (HCNs) in subsidiary staffing of MNCs (Chung and Furusawa, 2015). 
Researchers have examined the degrees of standardisation by assessing the similarity between parent and subsidiary firm practices (Björkman, 2006; Chung, Sparrow, and Bozkurt, 2014; Rosenzweig, 2006) and identified various institutional and cultural influences on such practices. These include the 'country of origin effect', 'local effect', and 'dominance effect' (Chung and Furusawa, 2015; Pudelko and Harzing, 2007). Linked to the assumption that MNCs want to standardise policies and practices globally has been the literature on the transfer of HRM practices - usually from HQ to the subsidiaries (Edwards et al., 2010) - and a wider literature about the link between HRM practices in MNCs and knowledge transfer (e.g. Minbaeva et al., 2013). Research that has been able to compare MNCs with indigenous organisations indicates that MNCs do bring in innovative HRM practices but that they tend to manage their staff in ways that are broadly similar to local organisations (Brewster, Wood, and Brookes, 2008; Farndale, Brewster, and Poutsma, 2008). There has been much less HRM research applying the learning from the international business literature that there may be country or subsidiary-specific advantages (Rugman and Verbeke, 2001) that mean an MNC may not want to standardise practices. MNCs often move their operations to other countries precisely because they wish to take advantage of the differences in, for example, the lower standards of living, the lower standards of legislation on health and safety, the restrictions on trade unions and the absence of environmental concerns, all of which lead to lower labour costs and, hence, to cheaper production (Dunning and Lundan, 2008).

Taking a rather different perspective, proponents of the dominance effect (Pudelko and Harzing, 2007; Smith and Meiksins, 1995), argue that certain economies 
dominate executive thinking and lead to intentions to copy what are seen as 'best practices' from that country, even if they are different from HQ practices. In the 1970s and 1980s Japan dominated management thinking, with efforts to understand, and copy, the 'Japanese economic miracle' and the crucial role of Japanese HRM (Drucker, 1971). Since then, it has been the USA which has provided the dominant archetype.

The combination of the pressures towards standardisation, differentiation and dominance has resulted in various forms of hybridisation of HRM practices in the subsidiaries of MNCs (Chung, Sparrow, and Bozkurt, 2014; Edwards and Kuruvilla, 2005; Gamble, 2010). Different companies may have different points of balance between global integration and local responsiveness (Chung, Bozkurt, and Sparrow, 2012). Importantly, whilst standardisation may be implemented in one HRM practice, another may be defined by localisation (Brewster, Sparrow, and Harris, 2005; Chung, Sparrow, and Bozkurt, 2014), or the balance may vary within the hierarchy of each organisation. For example, in Panasonic, they promote the global integration of HRM for their 'corporate executive posts' whereas they seek for the HRM practices which can be culturally appropriate and competitive in the respective labour market for non-supervisory white-collar employees or blue-collar workers (Chung and Furusawa, 2015; Furusawa, 2008). Similarly, in Nissan, the performance evaluation system for managers is standardised worldwide, but for non-managerial positions is left to the discretion of each overseas subsidiary (within Nissan guidelines) (Furusawa, 2014).

Heenan, one of the early pioneers of IHRM, (Heenan and Perlmutter, 1979; Perlmutter, 1969) identified a series of different strategies that MNCs could adopt: poly-centric, where each subsidiary is managed by host country nationals ('When in Rome, do as the Romans do' and only financial results were monitored and controlled 
for); ethnocentric, where everything was controlled from headquarters, mainly by a large cohort of HQ expatriates in the host subsidiaries; geocentric, where all parts of the global operation were mined for best practice and the best and most promising people were transferred to where they could be of most value or learn most, irrespective of their origin; and a less well-defined regiocentric category, where regional headquarters performed a similar role to that of the global headquarters within their region and expatriates were transferred within the region but not beyond.

Another section of the IHRM literature addresses issues related specifically to expatriation - moving people across national borders (Dowling, Festing, and Engels, 2008; Harzing and Pinnington, 2011; Stahl, Björkman, and Morris, 2012). This expatriation literature was initially based on MNCs from the United States of America and Europe and was focused on concerns about selecting and sending people abroad. It has developed into a more detailed analysis of the antecedents, practicalities and outcomes of international working (Fang et al., 2010). It has been assumed that a key part of the job of an expatriate is to transfer knowledge to the subsidiaries: either their own experience and skills (Gaur, Delios, and Singh, 2007; Hébert, Very, and Beamish, 2005; Minbaeva and Michailova, 2004; Tan and Mahoney, 2006) or that of the total organisation, from a headquarters perspective (Gabberty and Thomas, 2007; Hocking, Brown, and Harzing, 2004). As Fang et al. (2010) point out, the few studies that had been conducted prior to theirs (they cite Björkman, Barner-Rasmussen, and Li, 2004; and Gupta and Govindarajan, 2000) had found little evidence of a link between expatriation and knowledge transfer.

In the case of Japanese MNCs, it seems to be clear that they make more use of expatriates from Japan, and that these Japanese expatriates tend to stay in their host 
countries for longer than other expatriates (Furuya et al., 2007; Tungli and Peiperl, 2009). The existing studies that have been conducted, have generally pointed to the slow progress made in localising top management positions at the overseas subsidiaries of Japanese MNCs (Furusawa, 2008; Harzing, 2001 and 2004; Kopp, 1994 and 1999; Yoshihara, 2007), though there is evidence of some progress (Beamish and Inkpen, 1998; Chung and Furusawa, 2015). The 'rice paper ceiling', as Kopp (1994) called it, creates problems in attracting and retaining the most talented local individuals for their overseas operations (Keeley, 2001; Kopp, 1994). Consequently, the existence of a persistent ceiling for non-Japanese has been seen as their 'Achilles heel' (Bartlett and Yoshihara, 1988).

The competitive edge for MNCs today depends on the ability to access, connect, and leverage knowledge from far-flung sources (Evans, Pucik, and Björkman, 2010; Kogut and Zander, 1992) but means of accessing it may vary. Accessing complex knowledge embedded in local environments may be best done by local managers who share an understanding of the local context, culture, and values (Doz, Santos, and Williamson, 2001, p. 153) and can exploit their position as host country nationals and local insiders. However localisation is a step on the journey toward transnational development and not an end in itself (Evans, Pucik, and Barsoux, 2002, p. 191). In the process of connecting and leveraging knowledge, global collaboration amongst managers with cultural and geographical diversity becomes imperative.

Combining the viewpoints of globalisation/localisation and international staffing policy, we create a framework of 'transnational human resource management' to explain the forms and outcomes of MNC integration (Figure I). This distinguishes between normative and systems approaches to integration. 


\section{$<<$ Figure here $>>$}

Normative integration refers to worldwide socialisation by disseminating a global corporate philosophy throughout the company. Within network-type organisations such as the transnational company, the flow of knowledge and information between the headquarters and their overseas subsidiaries can be complex. In particular, knowledge embedded in the local environment is often intangible or 'sticky' and difficult to transfer through the hierarchical and structural mechanisms of coordination and control, or information technology (Doz, Santos, and Williamson, 2001; Evans, Pucik, and Björkman, 2010; Fang et al., 2010; Furusawa, 2008; Harzing, 2001; Kopp, 1994). The senders and receivers of the knowledge must trust each other (Szulanski, 1996). Through normative integration the organisation has to complement its reliance on traditional modes of information processing with attention to more lateral or horizontal ones, through socialisation and co-ordination policies, minimizing the necessity for centralized headquarters control or bureaucratic procedures (Evans, Pucik, and Barsoux, 2002, p. 24) and the development of the 'global glue' (Evans, 1992) of a coherent and accepted philosophy. Normative integration requires recruitment and selection, induction and training programmes to be based on a clear corporate philosophy or set of values, selective promotion of individuals who have internalized the core values of the organisation, corporate ceremonies and symbols, and so on (Deal and Kennedy, 1982; Evans, Pucik, and Björkman, 2010; Furusawa, 2008). Expatriation can also be an effective tool to promote the process of transnational socialisation (Edström and Galbraith, 1977; Mäkelä and Brewster, 2009) with an expatriate acting as a 
boundary-spanner (Fang et al., 2010; Yagi and Kleinberg, 2011). Global project teams or task forces can perform the same function (Harzing, 1999). Regular employee opinion surveys such as the 'global credo survey' at Johnson \& Johnson can be utilised to check and ensure the dissemination of the corporate philosophy (Furusawa, 2008).

The other necessary type of integration is systems integration which involves globally integrated personnel systems. The ultimate goal of geocentrism is a worldwide standardised approach in both headquarters and subsidiaries. The firm's subsidiaries are thus neither satellites nor independent city states, but parts of a whole whose focus is on worldwide objectives as well as local objectives. Senior executives with this orientation seek the best person, regardless of nationality, to solve the company's problems anywhere in the world (Heenan and Perlmutter, 1979, p. 13). The fundamental advantage of multinational companies over domestic ones lies in the global-wide availability of capable human resources (Vernon, 1971). The notions of the transnational or metanational company assume situations wherein ideas are exchanged and human resources are utilised across borders to create and diffuse innovation on a global basis. In order to develop these organisational capabilities, global headquarters must implement systems to make the best use of their competent employees around the world. The consistency of company HRM practices across the globe creates cross-border equity and comparability, and alignment of systems internationally to facilitate an internal labour market (Farndale, Brewster, and Poutsma, 2008, p. 2006). This standardisation is likely to originate from a parent country practice (Björkman, 2006; Chung, Sparrow, and Bozkurt, 2014; Rosenzweig, 2006), but it may arise from an integrative approach in which the best practices are sought from parent and subsidiaries (Taylor, Beechler, and Napier, 1996). Systems integration encompasses globally 
standardised systems of job grades, personnel appraisals, and compensation (Furusawa, 2008; Hanada, 1988). Global HRM databases including 'knowledge yellow pages' or a 'who's who' of in-house experts may play an important role as an infrastructure to promote globally optimized utilisation of human resources and global exchange of knowledge (Doz, Santos, and Williamson, 2001; Stroh and Caligiuri, 1998). Leading MNCs often have global talent management and succession planning programmes (Al Ariss, 2014; Furusawa, 2014; McDonnell and Collings, 2011), and they use measures of globally uniform competency or leadership approaches, clearly indicated career paths for high-potentials, and global job-posting systems to facilitate the process. Some companies build personal relationship amongst their HR managers through regular worldwide HRM department meetings aiming to match supply and demand for talent across the national boundaries (Furusawa, 2008).

In our 'transnational human resource management' model, practices for normative and systems integration will lead to 'social capital' and 'geocentric staffing' respectively. Social capital (Inkpen and Tsang, 2005; Kostova and Roth, 2003) concerns trust and has been defined as 'the sum of the actual and potential resources embedded within, available through and derived from the network of relationships possessed by an individual or social unit' (Nahapiet and Ghoshal, 1998, p. 243). Social capital can be either individual or organisational, depending on the perspective from which the relevant network of relationships is assessed. Social capital is in part a function of the centrality of an actor (an expatriate for example) to a network (Kilduff and Tsai, 2003), so there is a structural component to social capital, manifested in the attributes of an actor's network position (Espedal, Gooderham, and Stensaker, 2013; Tsai, 2000).

Globally shared values and norms across those networks cultivate trust and 
human networks amongst the organisation members. Shared context will sublimate into global corporate culture which can act as a psychological glue to bind its sites together into a single network and enhance the exchange of knowledge (Doz, Santos, and Williamson, 2001). This communal sense of identity limits the risk of opportunistic and self-interested behaviour and promotes global collaboration (Evans, Pucik, and Björkman, 2010; Kogut and Zander, 1992). Transnational socialisation in the global corporate philosophy nurtures a global mindset and dual allegiance to both the headquarters and the local operation (Evans, Pucik, and Björkman, 2010; Gupta and Govindarajan, 2002; Sparrow, Brewster, and Harris, 2004). Global mindset is a set of attitudes that predispose individuals to cope constructively with competing priorities of local versus global rather than advocating one dimension at the expense of the other (Evans, Pucik, and Barsoux, 2002, p. 308). This leads to our first hypothesis:

H1. There is a positive association between practices for normative integration in international HRM and the nurturing of social capital.

Geocentric staffing (Perlmutter, 1969), or globally optimized utilisation of human resources will require globally standardised personnel systems to facilitate multi-directional international transfer of human resources between the headquarters and their foreign-affiliated companies as well as amongst overseas subsidiaries (Gooderham, Minbaeva, and Pedersen, 2011; Mäkelä, Björkman, and Ehrnrooth, 2009). The global consistency of HRM practices created by systems integration will ease this process. From the viewpoint of employees, this means that capable people can be promoted irrespective of their nationalities, in line with the classical geocentric 
philosophy. Global career opportunities are presented to local employees as well as headquarters staff. Localisation policies alone cannot attract and retain the best and brightest talent in each local labour market (Heenan and Reynolds, 1975). Through systems integration, MNCs will be able to build up their 'employer brand' to recruit and develop capable future leaders. Hence, our second hypothesis:

H2. There is a positive association between practices for systems integration in international HRM and increasing level of geocentric staffing.

The final construct of the model is what we call 'transnationality'. To be transnational requires exchange of information amongst dispersed actors. Social capital at the MNC level can facilitate the information exchange amongst the dispersed actors in the process of transnational innovation, by helping to overcome institutional/cultural distances (Inkpen and Tsang, 2005; Reagans and McEvily, 2003). But, since much knowledge is tacit, the exchange of information would not be enough, by itself, to facilitate innovation and sharing of innovations (Gupta and Govindarajan, 2002). Thus, moving people would be also necessary in addition to the exchange of information (Minbaeva and Michailova, 2004). We acknowledge of course that the knowledge transfer role may, conversely, play a part on determining the MNCs' expatriation policies (Bonache and Brewster, 2001). Social capital at the MNC level and geocentric staffing (global mobility) would be the two conditions to enable an MNC to be transnational.

Transnationality in our model encompasses the transnational innovation processes we touched upon earlier and has three major characteristics. The first is that foreign subsidiaries become innovation centres. The transnational company, expecting 
to benefit from their environmental diversity rather than perceiving it as a constraint, may aim to get their subsidiaries to act as innovation centres in their global network (Evans, Pucik, and Björkman, 2010). It is assumed that involvement with local employees and foreign subsidiaries through both normative and systems integration will give them the energy and motivation that lead to innovation. The second characteristic is its multi-dimensional innovation process where the needs sensed in one country are fulfilled by developments from another, or innovations are created by linking knowledge of different units at both the headquarters and subsidiaries. In the conventional theory of international management, the source of each innovation was thought to exist within the boundaries of a country (Bartlett and Ghoshal, 1995; Fayerweather, 1969). On the other hand, the transnational company is grounded in a mentality that utilises local knowledge for global interests. The crossbreeding of knowledge that yields innovation is expected through mutual trust amongst key persons and multi-directional transfers of employees. The third characteristic is the global transfer and utilisation of innovation. The 'not invented here' syndrome has been seen as a serious obstacle to the global competitiveness of multinational companies (Katz and Allen, 1982). Such parochial mindsets may perhaps be overcome by nurturing a global mindset in local managers and global interaction of human resources. So, this study tested our third hypothesis.

H3. Both social capital and geocentric staffing are associated with increasing level of transnationality.

\section{Methodology}

We conducted a questionnaire survey of Japanese multinational companies to test the hypotheses and analyse the relationship amongst the constructs in our transnational human resource management model. The survey was sent to the Japanese MNCs in membership of the Japan Society for Chief Human Resources Officer (a non-profit organisation based in Tokyo). The organisation has 213 leading Japanese MNCs as members and constituted a good target group for our survey. We discussed the design of the questionnaire in detail with the society prior to finalising it, though we did not carry 
out a formal pilot survey. We mailed the questionnaire, in Japanese, to the Chief Human Resources Officer of each company.

Responses were obtained from 93 companies: a response rate of 43.7 per cent. 82 of the responding companies belonged to the manufacturing sector. All the respondents apart from two companies were categorized as 'large company' by the standards of the Companies Act in Japan, which means they represent a cohort of leading Japanese MNCs.

Apart from demographic questions, all questions in the survey were based on our framework of transnational human resource management and designed to be answered using a 5-point Likert-type scale. The scale ranged from 1=entirely untrue or incorrect to $5=$ exactly true or correct. Practices for normative integration and systems integration were operationalized through a thirteen-item scale for each, inquiring about the extent to which the company used each practice. For normative integration, we examined the use of measures such as recruitment and selection, induction and training programmes, personnel evaluation and assessment, international assignments and expatriation, corporate ceremonies and symbols, global project teams or task forces, and corporate philosophy-based decision making policy, as a means of disseminating the corporate philosophy. For systems integration, we explored the degrees of standardisation or universality in the practices of job grades, personnel appraisals, and compensation, and we also asked about the extent of practices like global HRM databases, succession planning or global talent management, globally uniform competency or leadership models, clearly indicated career paths for high-potentials, global job-posting and regular worldwide HRM department meeting. Two potential mediators in our model, namely social capital and geocentric staffing, were also 
assessed. For the first of these, we analysed the conditions of the mutual trust, global corporate culture, human networks, global mindset, and global mutual learning; whilst the degrees of international transfer and promotion opportunities beyond the national borders for host country nationals were examined for the latter. As to transnationality, five questions were asked to assess the frequency of subsidiary-originated innovation, reverse or horizontal transfer of innovation, globally linked innovation, and global utilisation of innovation.

In order to test our hypotheses, hierarchical multiple regression analysis was applied. Regarding Hypothesis 1 and Hypothesis 2, practices for normative and systems integration were taken as the independent variables. Factor analysis (principal factor method and Promax rotation) was performed to group the items into closely-related practices (See Appendix II and Appendix III). For normative integration, we extracted two clear factors with eigenvalues of more than 1.0, explaining 66.7 per cent of the total variance, by repeating the factor analysis while deleting items with a factor loading of less than 0.6. The factors in normative integration were labelled the personnel approach $(\alpha=0.857)$ composed of practices intended to infiltrate corporate philosophy through 'persons' such as top management at the headquarters, expatriates, founders or heroes of the company, or through global mobility of employees as well as global-wide company events or rituals; and value-based evaluation $(\alpha=0.825)$ composed of the items related to personnel evaluation and assessment systems based on corporate philosophy. Likewise, two clear factors with eigenvalues of more than 1.0 were extracted for systems integration, explaining 67.0 per cent of the total variance. The global talent management systems $(\alpha=0.837)$ comprise measures to identify, develop, and utilise global talent or high potentials, and the global comparability of HRM systems $(\alpha=0.910)$ 
covered global-wide systems of job grades, evaluation, and compensation. Social capital and geocentric staffing were the dependent variables. As a result of factor analysis of the two potential mediating variables (principal factor method and Promax rotation), one factor with eigenvalues of more than 1.0 was identified for each construct $(\alpha=0.869$; 0.818), suggesting each scale was uni-dimensional. Hypothesis 3 was tested with the potential mediators (social capital and geocentric staffing) as independent variables with the aggregated score of transnationality $(\alpha=0.909)$ as a dependent variable. Finally, we conducted mediation effect analyses to test the relationship amongst the five constructs in our model. We controlled for the type of business (non-manufacturing versus manufacturing) in the analyses.

\section{Findings}

\section{Descriptive statistics}

For normative integration practices, the mean of Factor 1 labelled personnel approach was 2.37 whilst that of Factor 2 (value-based evaluation) was 1.76, which suggests that Japanese MNCs work on global socialisation more through top management, expatriates, international assignment or projects, stories of company founders or heroes, or in-house ceremonies than through evaluation-linked measures. Regarding practices for systems integration, the scores of both factors (global talent management systems and global comparability of HRM systems) were below 2.00, which means the overall scores were

still lower than those of normative integration. No statistically significant differences were found between non-manufacturing and manufacturing companies (Table I).

\section{$<<$ Table I $>>$}


For social capital, all the scores of Japanese MNCs were around the midpoint. The highest item was 'relationship of mutual trust between the senior managers of the headquarters and overseas subsidiaries' (3.29) whereas the lowest was 'organisational climates to emphasize global mutual learning' (2.65). All the means of manufacturing companies were higher, with a statistically significant difference on one item (Table II). For the aspect of geocentric staffing, it is worth noting that the most of the scores on global career opportunities for local employees in Japanese MNCs are below 2.00. Furusawa (2005, p. 85) referred to this as the 'second glass ceiling' where the careers of local staffs are confined to the positions in each subsidiary, though they have entered a globally operating company. They are forced to act as a local player, whilst the Japanese staffs from headquarters are expected to serve as global players. We did not find any significant differences between non-manufacturing and manufacturing companies (Table III).

\section{<<Table II >>}

\section{$<<$ Table III $>>$}

In terms of transnationality, all the means were below the midpoint. The results suggest that subsidiary-originated innovation, reverse or horizontal transfer of innovation, globally linked innovation, as well as global utilisation of innovation are not likely to happen very often in Japanese MNCs. The results of the t-test confirmed a difference on one item at the 10 per cent significance level between the two sample groups (Table IV). 


\section{$<<$ Table IV >>}

\section{Hierarchical multiple regression analyses}

The hypotheses were tested by way of hierarchical multiple regression analysis. As for Hypothesis 1, the control variable type of business (non-manufacturing=0, manufacturing=1) was entered in Step 1. In Step 2, the two factors comprising normative integration were included. As a result, one of the factors (personnel approach) was positively correlated with social capital $(\beta=0.569, \mathrm{p}<0.001)$, whilst the relationship between the control variable or value-based evaluation and dependent variable turned out to be insignificant. The $F$ values for $\Delta \mathrm{R} 2$ were statistically significant $(\mathrm{p}<0.001)$, indicating a proper fit between the regression model and the data. Therefore, Hypothesis 1 was largely supported (Table V).

\section{$<<$ Table V $>>$}

For Hypothesis 2, we found no significant relationship between the control variable and dependent variable in Step 1. In Step 2, the two factors of systems integration were added. The results show that both global talent management systems $(\beta=0.492$, $\mathrm{p}<0.001)$ and global comparability of HRM systems $(\beta=0.196, \mathrm{p}<0.05)$ were positively associated with geocentric staffing whereas the control variable remained insignificant. As the addition of the two factors increased the R 2 by 35.0 points $(p<0.001)$, the model confirms the robustness of our results. This provides support for Hypothesis 2 (Table $\mathrm{VI})$. 


\section{<Table VI>}

For Hypothesis 3, we tested the influence of social capital and geocentric staffing on transnationality. No effect of the control variable on the dependent variable was discovered in Step 1. As a second step, the two factors of our potential mediators were entered. The results indicate that both social capital and geocentric staffing were associated with transnationality, having positive coefficients at the 0.001 significance level, whilst the influence of the control variable was insignificant. The addition of the independent variables resulted in a significant improvement over the model's explanatory power as $\Delta \mathrm{R} 2 \quad(\mathrm{p}<0.001)$ provided a statistical significance. Thus Hypothesis 3 was supported (Table VII).

All VIF scores in our hierarchical multiple regression analyses were well below 2.00, suggesting that multicollinearity was not a major problem in our study.

\section{$<<$ Table VII $>>$}

\section{Mediation effect analyses}

Finally, we tested the relationship amongst the five major constructs in our transnational human resource management model with social capital and geocentric staffing as potential mediators. Following Baron and Kenny's (1986) approach, this research examined the mediation effects by conducting additional regression analyses. For social capital, we examined the relationship between the two factors of normative integration 
and transnationality in Step 1. The results showed the personnel approach related positively to the dependent variable $(\beta=0.463, p<0.001)$. When we added the potential mediator (social capital) in Step 2, it correlated with transnationality whilst the statistically significant influence of the factors of normative integration disappeared (Table VIII). Regarding geocentric staffing, the relationship between the two factors of systems integration and transnationality was investigated in Step 1 and we found that global talent management systems was positively associated with the dependent variable $(\beta=0.342, \mathrm{p}<0.01)$. The inclusion of geocentric staffing in Step 2 demonstrated that the potential mediator had a statistically significant effect on transnationality $(\beta=0.540, p<0.001)$ whereas the coefficients for the factors of systems integration became insignificant (Table IX). As the additions of the mediators increased the R2 by 14.8 points $(\mathrm{p}<0.001)$ and 18.8 points respectively and the results of using the Bootstrap method showed a statistically significant decline in both the coefficients $(Z=4.754$, $\mathrm{p}<0.001 ; Z=3.752, \mathrm{p}<0.001)$, the robustness of our results has been confirmed. The findings indicated that both social capital and geocentric staffing have a complete mediation effect on the relationship between normative and systems integration and transnationality.

<<Table VIII >>

$<<$ Table IX >>

\section{Discussion}

Theoretical implications 
We developed a theoretical framework of transnational human resource management and demonstrated the validity of the model based on a questionnaire survey of Japanese MNCs. Through the empirical research, we specified dimensions of international human resource management which might contribute to the enhancement of transnationality of multinational companies, and provided explanations of the relationship between normative and systems integration in IHRM and transnationality by examining two underlying mediating variables. The results revealed that the practices for normative and systems integration were associated with increasing levels of social capital and geocentric staffing respectively, and that the social capital and geocentric staffing fully mediated the relationship between normative or systems integration and transnationality.

\section{Managerial implications}

In this study, we find both normative and systems integration in international HRM contribute to enhancing transnationality via social capital and geocentric staffing. Therefore, Japanese MNCs could broaden the scope of socialisation to those hired in host countries and could seek for global-wide management by utilising capable human resources regardless of nationality. Importantly, the two types of integration should function like the two wheels of a cart. Systems integration without normative integration might lead to opportunism and harm team spirit for the global collaborations beyond national borders. On the other hand, normative integration without systems integration is liable to be regarded as ethnocentrism and bring about the loss of capable employees. The biggest barrier to the development of global mindsets is the impression of local staff that one's passport counts more than one's talent (Evans, Pucik, and Barsoux, 2002, p. 390). 


\section{Limitations}

Like all research, this has limitations. Obviously, the data is restricted to Japanese MNCs and this may impact generalizability. It would also have been good to have more respondents. In addition, we have single respondents from the companies, although, as Huselid and Becker (2000) point out, if the research is looking for facts rather than opinions or feelings, then it is important to ensure the respondents are knowledgeable and able to answer the question. Adding in people who may not know the answers would weaken the research. Our survey method is cross-sectional and longitudinal perspectives would improve future research. Of course it is difficult with survey data to capture the richness and complexity of IHRM and we would also hope that future research would include case study and other qualitative approaches which, whilst they may not be able to indicate representativeness, do provide a more detailed picture of the dynamics within each firm.

\section{Conclusion}

This article makes a contribution to the literature by bridging the discussion between international business and international human resource management, and shedding light on the reality of global integration of IHRM in Japanese multinational companies.

Japanese MNCs international business strategy has been characterised as a 'global strategy' (Bartlett and Ghoshal, 1995, p. 249) or 'global projection' (Doz, Santos, and Williamson, 2001, p. 39) and seeks after global integration or global economy of scale by centralising authority, knowledge and information at the headquarters, at the cost of local responsiveness. This is a 'high integration-low responsiveness' strategy. On 
the other hand, the international human resource management strategies seem not to follow this route. Our empirical research shows that Japanese MNCs have some way to go to reach transnationality in both normative and systems integration in IHRM, as well as in social capital and geocentric staffing. As with the previous literature which points to the slow progress of localisation of top management positions at their overseas subsidiaries (Furusawa, 2008; Harzing, 2001 and 2004; Kopp, 1994 and 1999, Yoshihara, 2007), our evidence indicates their international human resource management is neither globally integrated nor localised: it is, in other words, ad hoc. The gap between the high integration of their business strategy and the low integration of their IHRM practices may suggest that their tightly centralized strategy has been realised solely through Japanese employees at the headquarters and in the overseas subsidiaries. International HRM for Japanese MNCs has been almost synonymous with management of Japanese expatriates and host country nationals have not been treated as potential international managers by the headquarters. The low level normative integration might generate mutual distrust between Japanese expatriates and local managers. Simultaneously, the low level of systems integration may amount to little more than a medley of stand-alone HRM practices. This reduces the possibilities of optimum utilisation of human resources on a global basis and means Japanese MNCs find it difficult to attract and retain the most talented persons due to the 'second glass ceiling'. As a result of the increased importance of overseas operations, non-Japanese employees are already a majority in many Japanese MNCs today. This indicates that future growth of Japanese MNCs will be dependent on their international HRM to attract, develop, motivate, and retain the best and brightest local talents. 


\section{References}

Al Ariss, A. (Ed.) (2014), Global Talent Management: Challenges, Strategies, and Opportunities, Springer, Heidelberg.

Baron, R. A. and Kenney, D. A. (1986), "Moderator-mediator variable distinction in social psychological research: Conceptual, strategic, and statistical considerations", Journal of Personality and Social Psychology, Vol. 51 No. 6, pp. 1173-1182.

Bartlett, C. A. and Ghoshal, S. (1989), Managing across Borders: The Transnational Solution, Harvard Business School Press, Boston.

Bartlett, C. A. and Ghoshal, S. (1995), Transnational Management: Text, Cases, and Readings in Cross-border Management, Times Mirror Higher Education Group, Chicago.

Bartlett, C. A. and Ghoshal, S. (1998), Managing across Borders: The Transnational Solution ( $2^{\text {nd }}$ ed.), Harvard Business School Press, Boston.

Bartlett, C. A. and Yoshihara, H. (1988), "New challenges for Japanese multinationals: Is organization adaptation their Achilles heel?", Human Resource Management, Vol. 27 No. 1, pp. 19-43.

Beamish, P. W. and Inkpen, A. C. (1998), "Japanese firms and the decline of the Japanese expatriate", Journal of World Business, Vol. 33 No. 1, pp. 35-50.

Björkman, I. (2006), "International human resource management research and institutional theory", in Stahl, G. and Björkman, I. (Eds.), Handbook of Research in International Human Resource Management, Edward Elgar, Cheltenham, pp. 463-473.

Björkman, I., Barner-Rasmussen, W. and Li, L. (2004), "Managing knowledge transfer 
in MNCs: The impact of headquarters control mechanisms", Journal of International Business Studies, Vol. 35 No. 5, pp. 443-455.

Bonache, J. and Brewster, C. (2001), "Knowledge transfer and the management of expatriation", Thunderbird International Business Review, Vol. 43 No. 1, pp. $145-168$

Brewster, C., Sparrow, P. and Harris, H. (2005), "Toward a new model of globalizing human resource management", International Journal of Human Resource Management, Vol.16 No. 6, pp. 949-970.

Brewster, C., Wood, G. and Brookes, M. (2008), "Similarity, isomorphism and duality? Recent survey evidence on the HRM policies of MNCs", British Journal of Management, Vol. 19 No. 4, pp. 320-342.

Chung, C., Bozkurt, Ö. and Sparrow, P. (2012), "Managing the duality of IHRM: Unravelling the strategy and perceptions of key actors in South Korean MNCs", International Journal of Human Resource Management, Vol. 23 No. 11, pp. $2333-2353$

Chung, C. and Furusawa, M. (2015), "The HRM of foreign MNCs operating in Europe", Discussion Paper for the John H Dunning Centre for International Business at Henley Business School at the University of Reading, Reading, JHD-2015-04, pp. $1-22$.

Chung, C., Sparrow, P. and Bozkurt, Ö. (2014), “South Korean MNEs' international HRM approach: Hybridization of global standards and best practice", Journal of World Business, Vol. 49 No. 4, pp. 549-559.

Deal, T. E. and Kennedy, A. A. (1982), Corporate Cultures, Addison-Wesley Longman, New York. 
Dowling, J., Festing, M. and Engels, A. D. (2008), International Human Resource Management ( $5^{\text {th }}$ ed.), Thomson, Melbourne.

Doz, Y. L., Santos, J. and Williamson, P. (2001), From Global to Metanational: How Companies Win in the Knowledge Economy, Harvard Business School Press, Boston.

Drucker, P. F. (1971), "What we can learn from Japanese management", Harvard Business Review, Vol.49 No. 2, pp. 110-122.

Dunning, J. H. and Lundan, S. M. (2008), Multinational Enterprises and the Global Economy, Edward Elgar, Cheltenham.

Eden, L. (2003), "A critical reflection and some conclusions on OLI", in Cantwell, J. and Narula, R. (Eds.) International Business and the Eclectic Paradigm: Developing the OLI Framework, Routledge, London, pp.277-297.

Edström, A. and Galbraith, J. R. (1977), “Transfer of managers as a coordination and control strategy in multinational organizations", Administrative Science Quarterly, Vol. 22 No. 2, pp. 248-263.

Edwards, T., Edwards, P., Ferner, A., Marginson, P. and Tregaskis, O. (2010), "Multinational companies and the diffusion of employment practices from outside the country of origin: Explaining variation across firms", Management International Review, Vol. 50 No. 5, pp. 613-634.

Edwards, T. and Kuruvilla, S. (2005), "International HRM: National business systems, organizational politics and the international division of labour in MNCs", International Journal of Human Resource Management, Vol. 16 No. 1, pp. 1-21.

Espedal, B., Gooderham, P. and Stensaker, I. G. (2013), “Developing organizational social capital or prima donnas in MNEs? The role of global leadership development programs", Human Resource Management, Vol. 52 No. 4, pp. 607-625. 
Evans, P. (1992), "Developing leaders and managing development", European Management Journal, Vol. 10 No. 1, pp. 1-9.

Evans, P., Pucik, V. and Barsoux, J.-L. (2002), The Global Challenge: International Human Resource Management, McGraw Hill-Irwin, New York.

Evans, P., Pucik, V. and Björkman, I. (2010), The Global Challenge: International Human Resource Management (2 $2^{\text {nd }}$ ed.), McGraw Hill-Irwin, New York.

Fang, Y., Jiang, G.-L. F., Makino, S. and Beamish, P. W. (2010), "Multinational firm knowledge, use of expatriates, and foreign subsidiary performance", Journal of Management Studies, Vol. 47 No. 1, pp. 27-54.

Farndale, E., Brewster, C. and Poutsma, E. (2008), “Coordinated vs. liberal market HRM: The impact of institutionalization on multinational firms", International Journal of Human Resource Management, Vol. 19 No. 11, pp. 2004-2023.

Fayerweather, J. (1969), International Business Management: A Conceptual Framework, McGraw-Hill, New York.

Furusawa, M. (2005), "Nihonkigyou no kokusaijintekishigenkanri ni okeru 'daini no glass ceiling': 'Sekaiteki gakushuu nouryoku' kouchiku ni muketeno kadai” ("The 'second glass ceiling' in international human resource management of Japanese companies: Challenges to "worldwide learning capabilities"'), Osaka Shougyou Daigaku Ronshuu (The Review of Osaka University of Commerce), No. 137, pp. 75-90.

Furusawa, M. (2008), Global Jintekishigen Kanriron (The Theory of Global Human Resource Management), Hakutou Shobou, Tokyo.

Furusawa, M. (2014), “Global talent management in Japanese multinational companies: The case of Nissan Motor Company", in Al Ariss, A. (Ed.), Global Talent 
Management: Challenges, Strategies, and Opportunities, Springer, Heidelberg, pp. 159-170.

Furuya, N., Stevens, M. J., Bird, A., Oddou, G. and Mendenhall, M. (2007), "Managing the learning and transfer of global management competence: Antecedents and outcomes of Japanese repatriate effectiveness", Journal of International Business Studies, Vol. 40 No. 2, pp. 200-215.

Gabberty, J. W. and Thomas, J. D. E. (2007), "Knowledge management research imperatives governing multinational corporate expansion”, Multinational Business Review, Vol. 15 No. 3, pp. 105-128.

Gamble, J. (2010), "Transferring organizational practices and the dynamics of hybridization: Japanese retail multinationals in China", Journal of Management Studies, Vol. 47 No. 4, pp. 705-732.

Gaur, A. S., Delios, A. and Singh, K. (2007), "Institutional environments, staffing strategies and subsidiary performance", Journal of Management, Vol. 33 No. 4, pp. 611-636.

Gooderham, P. N., Minbaeva, D. and Pedersen, T. (2011), “Governance mechanisms for the promotion of social capital for knowledge transfer in multinational corporations”, Journal of Management Studies, Vol. 48 No. 1, pp. 123-150.

Gupta, A. and Govindarajan, V. (2000), "Knowledge flows within multinational corporations", Strategic Management Journal, Vol. 21 No. 4, pp. 473-496.

Gupta, A. K. and Govindarajan, V. (2002), "Cultivating a global mindset", Academy of Management Executive, Vol. 16 No. 1, pp. 116-126. 
Hanada, M. (1988), "Global-senryaku o sasaeru jinji-system no tenkaihou” ("How to develop human resource management system supporting global strategy"), Diamond Harvard Business, Vol. 13 No. 4, pp. 55-64.

Harzing, A.-W. K. (1999), "MNE staffing policies for the managing director position in foreign subsidiaries: The results of an innovative research method", in Brewster, C. and Harris, H. (Eds.), International HRM: Contemporary Issues in Europe, Routledge, London, pp. 67-88.

Harzing, A.-W. (2001), “Who's in charge: An empirical study of executive staffing practices in foreign subsidiaries", Human Resource Management, Vol. 40 No. 2, pp. $139-158$.

Harzing, A.-W. (2004), "Composing an international staff”, in Harzing, A.-W. and Ruysseveldt, J. V. (Eds.), International Human Resource Management $\left(^{\text {nd }}\right.$ ed.), SAGE Publications, London, pp. 251-282.

Harzing, A.-W. and Pinnington, A. (Eds.) (2011), International Human Resource Management ( $3^{\text {rd }}$ ed.), SAGE Publications, London.

Heenan, D. A. and Perlmutter, H. V. (1979), Multinational Organization Development, Addison-Wesley, Reading, MA.

Heenan, D. A. and Reynolds, C. (1975), “RPO's: A step toward global human resource management”, California Management Review, Vol. 18 No. 1, pp. 5-9.

Hébert, L., Very, P. and Beamish, P. W. (2005), "Expatriation as a bridge over troubled water: A knowledge-based perspective applied to cross-border acquisitions", Organization Studies, Vol. 26 No. 10, pp. 1455-1476. 
Hocking, B., Brown, M. and Harzing, A.-W. (2004), "Knowledge transfer perspective of strategic assignment purposes and their path-dependent outcomes", International Journal of Human Resource Management, Vol. 15 No. 3, pp. 565-586.

Huselid, M. and Becker, B. E. (2000), "Comment on 'Measurement error in research on human resources and firm performance: How much error is there and how does it influence effect size estimates?' by Gerhart, Wright, McMahan, and Snell”, Personnel Psychology, Vol. 53 No. 4, pp. 835-854.

Inkpen, A. C. and Tsang, E. W. K. (2005), "Social capital, networks and knowledge transfer", The Academy of Management Review, Vol. 30 No. 1, pp. 146-165.

Janssen, O. (2000), "Job demands, perceptions of effort-reward fairness and innovative behavior", Journal of Occupational and Organizational Psychology, Vol. 73 No. 3, pp. 287-302.

Katz, R. and Allen, T. J. (1982), "Investigating the not invented here (NIH) syndrome: A look at the performance, tenure, and communication patterns of $50 \mathrm{R} \& \mathrm{D}$ project groups", $R$ \& D Management, Vol. 12 No. 1, pp. 7-20.

Kaufman, B. E. (Ed.) (2014), The Development of Human Resource Management across Nations, Edward Elgar, Cheltenham.

Keeley, T. D. (2001), International Human Resource Management in Japanese Firms, Palgrave Macmillan, New York.

Kilduff, M. and Tsai, W. (2003), Social Networks and Organizations, SAGE Publications, London.

Kogut, B. and Zander, U. (1992), "Knowledge of the firm, combinative capabilities and the replication of technology", Organization Science, Vol. 3 No. 3, pp. 383-397. 
Kopp, R. (1994), "International human resource policies and practices in Japanese, European, and United States multinationals", Human Resource Management, Vol. 33 No. 4, pp. 581-599.

Kopp, R. (1999), “The rice-paper ceiling in Japanese companies: Why it exists and persists", in Beechler, S. L. and Bird, A. (Eds.), Japanese Multinationals abroad: Individual and Organizational Learning, Oxford University Press, New York/Oxford, pp. 107-128.

Kostova, T. and Roth, K. (2003), "Social capital in multinational corporations and a micro-macro model of its formation", The Academy of Management Review, Vol. 28 No. 2, pp. 297-317.

Mäkelä, K., Björkman, I. and Ehrnrooth, M. (2009), "MNC subsidiary staffing architecture: Building human and social capital within the organisation", International Journal of Human Resource Management, Vol. 20 No. 6, pp. 1273-1290.

Mäkelä, K. and Brewster, C. (2009), “Interunit interaction contexts, interpersonal social capital, and differing levels of knowledge sharing", Human Resource Management, Vol. 48 No. 4, pp. 591-614.

McDonnell, A. and Collings, D. G. (2011), "The identification and evaluation of talent in MNEs", in Scullion, H. and Collings, D. G. (Eds.), Global Talent Management, Routledge, New York, pp. 56-73.

Minbaeva, D. B. and Michailova, S. (2004), "Knowledge transfer and expatriation in multinational corporations: The role of disseminative capacity", Employee Relations, Vol. 26 No. 6, pp. 663-679. 
Minbaeva, D. B., Pedersen, T., Björkman, I. and Fey, C. F. (2013), “A retrospective on: MNC knowledge transfer, subsidiary absorptive capacity and HRM", Journal of International Business Studies, Vol. 45 No. 1, pp. 38-51.

Nahapiet, J. and Ghoshal, S. (1998), "Social capital, intellectual capital, and the organizational advantage", The Academy of Management Review, Vol. 23 No. 2, pp. 242-266.

Narula, R. (2010), "Keeping the eclectic paradigm simple", Multinational Business Review, Vol. 18 No. 2, pp. 35-50.

Pangarkar, N. and Yuan, L. (2009), "Location in internationalisation strategy: Determinants and consequences", Multinational Business Review, Vol. 17 No. 2, pp. $37-68$.

Perlmutter, H. V. (1969), "The tortuous evolution of the multinational corporation", Columbia Journal of World Business, Vol.4 No. 1, pp. 9-18.

Pudelko, M. and Harzing, A.-W. (2007), “Country-of-origin, localization, or dominance effect? An empirical investigation of HRM practices in foreign subsidiaries", Human Resource Management, Vol. 46 No. 4, pp. 535-559.

Reagans, R. and McEvily, B. (2003), "Network structures and knowledge transfer: The effects of cohesion and range", Administrative Science Quarterly, Vol. 48 No. 2, pp. 240-267.

Rosenzweig, P. (2006), "The dual logic behind international human resource management: Pressures for global integration and local responsiveness", in Stahl, G. and Björkman, I. (Eds.), Handbook of Research in International Human Resource Management, Edward Elgar, Cheltenham, pp. 36-48. 
Rugman, A. and Verbeke, A. (2001), "Subsidiary specific advantages in multinational enterprises”, Strategic Management Journal, Vol. 22 No. 3, pp. 237-250.

Smith, C. and Meiksins, P. (1995), "System, society and dominance effects in cross-national organisational analysis", Work, Employment and Society, Vol. 9 No. 2, pp. 241-267.

Sparrow, P., Brewster, C. and Harris, H. (2004), Globalizing Human Resource Management, Routledge, London.

Stahl, G., Björkman, I. and Morris, S. (2012), Handbook of Research in International $\operatorname{HRM}\left(2^{\text {nd }}\right.$ ed. $)$, Edward Elgar, London.

Stroh, L. K. and Caligiuri, P. M. (1998), "Increasing global competitiveness through effective people management", Journal of World Business, Vol. 33 No. 1, pp. 1-16.

Szulanski, G. (1996), "Exploring internal stickiness: Impediments to the transfer of best practice within the firm”, Strategic Management Journal, Vol. 17 (Winter Special Issue), pp. 27-43.

Tan, D. and Mahoney, J. T. (2006), "Why a multinational firm chooses expatriates: Integrating resource-based, agency and transaction costs perspectives", Journal of Management Studies, Vol. 43 No. 3, pp. 457-484.

Taylor, S., Beechler, S. and Napier, N. (1996), "Toward an integrative model of strategic international human resource management", Academy of Management Review, Vol. 21 No. 4, pp. 959-985.

Tsai, W. (2000), "Social capital, strategic relatedness, and the formation of intra-organizational linkages", Strategic Management Journal, Vol. 21 No. 9, pp. 925-939.

Tungli, Z. and Peiperl, M. (2009), "Expatriate practices in German, Japanese, U.K., and 
U.S. multinational companies: A comparative survey of changes", Human Resource Management, Vol. 48 No. 1, pp. 153-171.

Vernon, R. (1971), Sovereignty at Bay: The Multinational Spread of U.S. Enterprises, Basic Books, New York.

Yagi, N. and Kleinberg, J. (2011), "Boundary work: An interpretive ethnographic perspective on negotiating and leveraging cross-cultural identity", Journal of International Business Studies, Vol. 42 No. 5, pp. 629-653.

Yoshihara, H. (2007), "Belated changes in international management of Japanese multinationals", Working Papers of Center for Management Studies at University of Nanzan, Nagoya, No. 604, pp. 1-20. 